\title{
Erratum
}

\section{Congo Grey Parrot Psittacus erithacus densities in oil palm plantation, agroforestry mosaic and protected forest in Southwest Cameroon - ERRATUM}

SASCHA DUEKER, DENIS KUPSCH, SERGE KADIRI BOBO,
ECKHARD W. HEYMANN and MATTHIAS WALTERT

The order of authors in the original published proof was incorrect. The article has now been corrected online.

The publisher apologises for this error.

\section{Reference}

Dueker, S., Kupsch, D., Bobo, S. K., Heymann, E. W. and Waltert, M. (2019). Congo Grey Parrot Psittacus erithacus densities in oil palm plantation, agroforestry mosaic and protected forest in Southwest Cameroon. Bird Conservation International. doi:10.1017/S0959270919000194. 